\title{
Pre-retirees' Plan Prior to Retirement of the Local Government Employees in the Province of Palawan
}

\author{
Edison C. Gabileo \\ College of Business and Management, Western Philippines University, Palawan, Philippines
}

Copyright $\mathrm{C} 2018$ by authors, all rights reserved. Authors agree that this article remains permanently open access under the terms of the Creative Commons Attribution License 4.0 International License

\begin{abstract}
The main objective of this study was to determine the pre-retirees' plan prior to retirement of the local government employees in the province of Palawan with the following specific objectives: identify the financial; health; social; financial, social, family and spiritual plans of pre-retirees prior to retirement; and suggestions of officials that can help meet the needs of pre-retirees in the LGU. On pre-retirement financial plan: plan the type of GSIS retirement option which will be more advantageous to them by asking advice from GSIS as to which of these retirement options to choose and plan to use expertise to continue earning even when retired; on the pre-retirement health plan was to practice healthy habits and recreational activities that are found in community; the family plan was to consider the spouse and immediate family members during pre-retirement planning and consult legal experts before executing wills and probate to inheritors before retirement; while on social plan: help the needy by joining community and civic organizations; the psychological plan was searching for a life-long learning by vicariously living the lives of people who have survived life's battles and traveling to sacred places (such as the Holy Land in Israel, grottos, Micah, Vatican in Rome and local churches) for spiritual plan; the conclusions was the pre-retirees' plan were all "well-planned" in selected well-being elements of pre-retirement, specifically in the areas of financial and health; but only "planned" in social, family and psychological; and the recommendations was provide a complete pre-retirement on financial, health, social, psychological, family and spiritual program in the local government units.
\end{abstract}

Keywords Retirees, Pre-retirement Financial, Health, Social, Psychological, Family and Spiritual Plan, LGU (Local Government Units)

\section{Introduction}

Retirement is a period of transition whose effects on the elderly differs from person to person. These effects on the physical, mental, psychological, and financial status of the retirees depend on their attitude toward and reason for retiring (Dhaval, Rashad, and Spasojevic, 2008). Many find difficulty adjusting to certain aspects of retirement, such as reduced income and altered social role and enticements. Hence, appropriate preparation for retirement may help the elderly cope with this life transition.

Pre-retirement preparation for LGU employees is to enjoy the four key elements of retirement for their peace of mind: financial security, health optimization, family support, and spiritual well-being (Lynch, 2013). On the financial side, the pre-retirement activities conducted by the LGU should advise the employees what to do with their pension and the money from their separation pay, the importance of savings, zero-liabilities, investing and budgeting.

The LGU pre-retirement program should emphasize the importance of the employees' healthy lifestyle for them to enjoy life without the pains of old age. Activities like engagement in sports, having regular physical/medical check-ups, and eating a healthy diet. A pre-retirement social-psychological program can be embraced by the LGU to encourage the pre-retirees to get involved in the community by sharing the skills and knowledge they have acquired from their work. The program can also lead to a good relationship with family, friends, and colleagues. A spiritual program is important in strengthening their faith and providing them anchor as they face life's problem. The researcher believes that a pre-retirement program can be best enforced first in the local government units and later on in the national level. It is for this reason that he developed a theoretical model that is lacking in the Civil Service Commission's functions that are limited to regulating the management and development of human resources, but silent on retirement planning. The research therefore is to consider what is on the mind and likelihood of these government pre-retirees during their retirement age that the LGU may take action through formulation a holistic pre-retirement program to help meet the needs of the pre-retirees in the Local Government Units. 


\section{Objectives}

A general objective of this study is to determine the pre-retirees' plans prior to retirement in selected local government units in the province of Palawan.

\section{Methodology}

There were one hundred forty three (143) pre-retiree respondents in selected municipalities in Palawan in a purposive-convenience procedure. A survey questionnaire was used in this study validated by the statistician. Survey questionnaires were distributed to the respondents who were given time to accomplish them. Secondary data were obtained from different sources such as local or international books, journals, the internet, and researches locally and internationally made. Extents of plans were used on the pre-retiree personnel respondents' plans. The researcher used the pre-retirement well-being benefits as financial, health, psychological, social and family, and spiritual plan (Nelson, 2010).

The respondents were assured of the confidentiality of their responses to give them freedom to express their views and to provide honest answers to the questions.

\section{Results and Discussion}

The plans of the pre-retiree respondents prior to retirement are categorized into: 1) financial, 2) health, 3) social and family, 4) psychological and 5) spiritual plans.

\section{The Financial Plans Prior to Retirement}

Table 1 shows the frequency distribution and mean rating of financial plan prior to retirement of the pre-retirees respondents in the LGUs. All items were verbally interpreted as "well-planned". Based on their ranks, the following were the respondents' plans: item (1.1) ranks $1^{\text {st }}$, plan the type of GSIS retirement option which will be more advantageous to them by asking advice from GSIS as to which of these retirement options to choose; item (1.6) ranks $2^{\text {nd }}$, plan to use expertise to continue earning even when retired; next is item (1.4) ranks $3^{\text {rd }}$, plan to enroll in savings literacy and have the initiative to acquire better financial management; item (1.3) ranks $4^{\text {th }}$, plan to enroll in savings literacy and have the initiative to acquire better financial management; item (1.5) ranks $5^{\text {th }}$, plan to save the money from separation or pension for emergency and medical allocation; and (1.2) plan to have a possible income by investing their saved money and other capital sources in reputable banks/institutions.

The pre-retirees' financial plan prior to their retirement was interpreted as "well-planned".

Although government employees have GSIS security for retirement, additional insurance and pension plan from reliable private insurance agency is still necessary. Probasco (2015) gave this suggestion in his Ten Commandments for Retirement: "thou shalt buy insurance".

The much-awaited retirement proceeds from GSIS have been to most retirees their ultimate source of income. It is their prerogative to choose which GSIS package they may decide to get, whether on installment or lump sum. It is SOP (Standard Operating Procedure) for the LGU officials to provide counseling services to pre-retirees as they process their papers prior to their retirement. Helman (2004) underscored the need to educate workers about their social security benefits, one of which is to provide a literacy program on GSIS pension plans for the government workers.

There is also a need to modify the pre-retirement savings of the LGU employees. Haveman (2006), speaking on a current policy issue on saving plans, suggested the adoption of one that could sustain the retiree's economic well-being after retirement. This is made possible by enabling the full maintenance of his estimated pre-retirement consumption. There would be a less serious problem even if new retirees have insufficient resources to enable them to maintain an above-poverty level lifestyle during retirement.

Financial factors that a pre-retiree needs to attend to are saving, investing, budgeting, and spending. Allessie (2011) emphasized the positive effect of financial literacy as a preparation for retirement. It is ideal that there be a viable financial literacy the LGUs provides to their pre-retiree employees, Doverspike (2003) found out that those who are financially secured have more positive attitude towards retirement.

Based on their expertise, retirees can continue working and, hence, earning, even during their retirement. Failing to prepare by prudent investing during their pre-retirement, retired employees can fall back on another way of acquiring income, to be reemployed by some agencies in need of their specialization. This is an employment opportunity for retirees who have higher educational attainments or competencies needed by those agencies. 
Table 1. Frequency Distribution and Mean Rating of Financial Plan Prior to Retirement of the Pre-retirees Respondents in the LGUs

\begin{tabular}{|l|c|c|c|c|c|c|}
\hline 1. Financial Plan & WP & P & NP & MR & VI & R \\
\hline 1.1. plan the type of GSIS retirement options which is more advantageous to them & 128 & 14 & 1 & 2.94 & WP & 1 \\
\hline $\begin{array}{l}\text { 1.2. plan to have a possible income by investing their saved money and other } \\
\text { capital sources in reputable banks/institutions }\end{array}$ & 108 & 31 & 4 & 2.59 & WP & 6 \\
\hline $\begin{array}{l}\text { 1.3 plan to enroll in savings literacy and have the initiative to acquire better } \\
\text { financial management }\end{array}$ & 91 & 43 & 9 & 2.71 & WP & 4 \\
\hline 1.4. plan to learn budgeting practices or through personal initiative & 93 & 47 & 3 & 2.79 & WP & 3 \\
\hline $\begin{array}{l}\text { 1.5. plan to save the money from separation or pension for emergency and } \\
\text { medical allocation }\end{array}$ & 128 & 4 & 11 & 2.61 & WP & 5 \\
\hline 1.6.plan to use expertise to continue earning even when retired & 93 & 46 & 4 & 2.90 & WP & 2 \\
\hline Overall Mean & & & 2.70 & WP & \\
\hline
\end{tabular}

Legend: 2.50 - 3.00 "Well-Planned" (WA); 1:50 - 2.490" Planned" (A); and 1.00 -1.49” Not Planned" (NA); MR: Mean Rating; R: Rank

Table 2. Frequency Distribution and Mean Rating of Pre-retiree Respondents' Health Plan Prior to Their Retirement

\begin{tabular}{|l|c|c|c|c|c|c|}
\hline 2 Health Plan & WP & P & NP & MR & VI & R \\
\hline $\begin{array}{l}\text { 2.1. maintain personal fitness through exercise that fits one's personality } \\
\text { and hobbies }\end{array}$ & 100 & 29 & 14 & 2.45 & P & 3 \\
\hline $\begin{array}{l}\text { 2.2.proper diet based on advice from experts and knowledgeable } \\
\text { informants }\end{array}$ & 113 & 19 & 11 & 2.61 & WP & 2 \\
\hline $\begin{array}{l}\text { 2.3. practice healthy habits and recreational activities found in community } \\
\text { group activities }\end{array}$ & 114 & 27 & 2 & 2.67 & WP & 1 \\
\hline 2.4. having a healthy lifestyle through personal discipline & 82 & 38 & 23 & 2.19 & P & 4 \\
\hline Overall Mean & & & 2.48 & $P$ & \\
\hline
\end{tabular}

Legend: 2.51 - 3.00 "Well-Planned” (WA); 1:51 - 2.50” Planned" (A); and 1.00 -1.50” Not Planned” (NA). MR: Mean Rating; R: Rank

\section{The Health Plans of Pre-retirees Prior to Retirement}

Table 2 shows the frequency distribution and mean rating of pre-retiree respondents' health plan prior to their retirement. Based on rank, these health plans are the following: item (2.3) ranked $1^{\text {st }}$, practice healthy habits and recreational activities that are found in community activities; item (2.2) ranks $2^{\text {nd }}$, proper diet based on advice from experts and other knowledgeable informants; the following items were interpreted "planned by the pre-retirees: (2.1) ranks $3^{\text {rd }}$ maintain personal fitness through exercise that fits one's personality and hobbies; and (2.4) ranks $4^{\text {th }}$, having a healthy lifestyle through personal discipline.

The pre-retirees' health plan prior to their retirement was interpreted as "well-planned".

Lee and Law's (2004) research findings on three main planning activities of middle-aged citizens in Hongkong included the following: pre-retirees' quitting bad habits relating to health; setting up retirement health fund; and exercising habitually. Although in the Philippines there is a PhilHealth membership fund for consultation and hospitalization benefits, still there is the need to strengthen the health insurance by encouraging pre-retirees to have additional health cards from reliable private-health providers. Probasco (2015) noted that government may develop a program to improve the pre-retirement health activities. During the FGD, HR officials assured that government is in support of health activities for pre-retirees. As a matter of fact, some LGUs have procured gym equipment to be used by the employees in their physical activity programs.

\section{Social and Family Plans Prior to Retirement}

Table 3 shows the frequency distribution and mean rating of pre-retiree respondents' social and family plan prior to their retirement. Based on rank, these are the following: item (3.1) ranks $1^{\text {st }}$, consider the spouse and immediate family members during pre-retirement planning; followed by item (3.4) ranks $2^{\text {nd }}$, help the needy by joining community and civic organizations; item (3.3) ranks $3^{\text {rd }}$, consult legal experts before executing wills and probate to inheritors; item (3.2) ranks $4^{\text {th }}$, consider the extended family members as part of pre-retirement plan; and lastly, item (3.6) ranks $5^{\text {th }}$, join political/cultural activities after retirement.

The pre-retirees' social plan prior to their retirement was verbally interpreted as "well-planned".

Another priory in the retirees' plan conforms to the ten commandments of Kingbeil's which says: "thou shalt keep thy wills, trusts, and beneficiary designations up to date (2011). The 10 Commandments of Senior Citizens further state: "place and enjoy what you saved. You deserve to enjoy it in your remaining healthy years. Travel if you can afford it. Don't leave anything for your children or loved ones to quarrel about; instead of helping, this can even cause more trouble when you are gone".

The first priority of pre-retirees on social plan was supported by some researchers. Lee and Law (2004) described social considerations as more concerned with friends and family members. While according to Maslow's hierarchy of needs, after the basic necessities that include financial and health needs, social needs come next. The data on social and family plans revealed that the Filipino pre-retiree respondents' affection and concern for family members and the community as priorities in their retirement plans. It was also revealed that their pre-retirement social plan had been given lesser priority to those given to their financial, spiritual, and health plans. 
Table 3. Frequency Distribution and Mean Rating of Pre-retiree Respondents' Social and Family Plan Prior to Their Retirement

\begin{tabular}{|l|c|c|c|c|c|c|}
\hline 4.3 Social and Family Plan & WP & P & NP & MEAN & VI & R \\
\hline $\begin{array}{l}3.1 \text { consider the spouse and immediate family members during pre-retirement } \\
\text { planning }\end{array}$ & 74 & 16 & 10 & 2.52 & WP & 1 \\
\hline 3.2 consider the extended family members as part of pre-retirement plan & 61 & 28 & 11 & 2.29 & $\mathrm{P}$ & 5 \\
\hline 3.3 consult legal experts before executing wills and probate to inheritors & 66 & 27 & 6 & 2.42 & $\mathrm{P}$ & 3 \\
\hline 3.4 help the needy by joining community and civic organizations & 69 & 22 & 9 & 2.44 & $\mathrm{P}$ & 2 \\
\hline $\begin{array}{l}3.5 \text { take the family members on vacation by saving for a vacation budget or } \\
\text { after the release of pension }\end{array}$ & 67 & 22 & 10 & 2.40 & $\mathrm{P}$ & 4 \\
\hline 3.6 join political/ cultural activities on retirement & 2 & 5 & 93 & 0.78 & $\mathrm{NP}$ & 6 \\
\hline Overall Mean & & 2.14 & $P$ & \\
\hline
\end{tabular}

Legend: 2.50 -3.00 “Well-Planned” (WA); 1:50 - 2.49” Planned” (A); and 1.00 -1.49” Not Planned” (NA)

Table 4. Frequency Distribution and Mean Rating of Pre-retiree Respondents' Psychological Plan

\begin{tabular}{|c|c|c|c|c|c|c|}
\hline 4. Psychological Plan & WP & $\mathrm{P}$ & NP & MR & VI & $\mathrm{R}$ \\
\hline $\begin{array}{l}\text { 4.1. joining yoga and other meditation sessions to be emotionally and spiritually } \\
\text { strong }\end{array}$ & 36 & 71 & 36 & 1.61 & $P$ & 3 \\
\hline 4.2. reading about the inspirational experiences of successful people & 51 & 79 & 13 & 1.92 & $\mathrm{P}$ & 2 \\
\hline $\begin{array}{l}\text { 4.3. searching for a life-long learning by vicariously living the lives of people who } \\
\text { have survived life's battles }\end{array}$ & 77 & 30 & 36 & 2.08 & $\mathrm{P}$ & 1 \\
\hline $\begin{array}{l}\text { 4.4. collecting inspirational quotes from literary works, music and other } \\
\text { worthwhile materials from books, the internet, and magazines }\end{array}$ & 14 & 63 & 64 & 1.25 & NP & 4 \\
\hline \multicolumn{4}{|l|}{ Overall Mean } & 1.75 & $P$ & \\
\hline
\end{tabular}

Legend: 2.51 - 3.00 "Well-Planned” (WA); 1:51 - 2.50” Planned” (A); and 1.00 -1.50” Not Planned” (NA). MR: Mean Rating. R: Rank

\section{Psychological Plan Prior to Retirement}

Table 4 shows the frequency distribution and mean rating of pre-retiree respondents' psychological plan. Based on rank, the following are contained in their plans: item (4.3) ranks $1^{\text {st }}$, "searching for a life-long learning by vicariously living the lives of people who have survived life's battles; item (4.2) ranks $2^{\text {nd }}$, "reading about the inspirational experiences of successful people"; next item (4.1) ranks $3^{\text {rd }}$, "joining yoga and other meditation sessions to be emotionally and spiritually strong"; and; lastly, item (4.4) ranks $4^{\text {th }}$, "collecting inspirational quotes from literary works, music and other worthwhile materials from books, the internet, and magazines",

The pre-retirees' psychological plan as based on the overall mean rating of 1.75 was verbally interpreted as "well-planned".

During their FGD, the HR discussants shared their perception that the retirement plans gave lesser priority to psychological activities than those assigned to financial, religion and health programs. The finding revealed the less likelihood of the pre-retirees' spending less time for psychological activities. Although the HR officers were not very vocal in airing their views about the psychological activities in the plan, they knew, however, that psychological well-being leads also to happiness. This view is supported by Ranchor (2004), who in his study, assumed that improving levels of happiness or satisfaction with life might also give rise to better health. Shultz and Wang (2011) concurred by suggesting that employers support their employees to be psychologically and financially prepared for retirement.

\section{Spiritual Plan Prior to Retirement}

Table 5 shows the frequency distribution and mean rating of pre-retiree respondents' spiritual plan prior to retirement. All items were verbally interpreted a "well-planned" on spiritual plan by the pre-retirees. Based on their ranks from highest to lowest, the spiritual plans of pre-retirees are arranged as follows: item (5.3) ranks $1^{\text {st }}$, "traveling to sacred places (such as the Holy Land in Israel, grottos, Micah, Vatican in Rome and local churches)"; followed by item (5.1) ranks $2^{\text {nd }}$, "current and active participation in religious activities to enhance personal, and spiritual aspects of life"; item (5.4) ranks $3^{\text {rd }}$, "meditating and reflecting on the scriptures, such as those in the Bible, Kor'an, other religious books, lives of saints or prophets; and lastly", item (5.2) ranks $4^{\text {th }}$, "regular attendance in church services, such as mass, Sunday school classes or prayer meetings".

The pre-retirees' spiritual plan was verbally interpreted as "well-planned".

Based on the findings shown on the table, there is a high level intensity of the pre-retirees for spiritual planning which is normal for the elderly (Atchey, 2004).

Item (5.1) shows the desire of pre-retirees to travel to religious places. They would like to visit places they did not have the chance to go to while working in the government and thereby gain knowledge they can share with others. Even item (5.4), "meditating and reflecting on readings from religious scriptures and other religious books and to explore the new places is included also in their plans when they retire". 
Table 5. Frequency Distribution and Mean Rating of Pre-retiree Respondents' Spiritual Plan

\begin{tabular}{|c|c|c|c|c|c|c|}
\hline \multirow{2}{*}{ 5. Spiritual Plan } & \multicolumn{3}{|c|}{$\mathrm{f}$} & \multirow{2}{*}{ MEAN } & \multirow{2}{*}{ VI } & \multirow{2}{*}{$\mathrm{R}$} \\
\hline & WP & $\mathrm{P}$ & NP & & & \\
\hline $\begin{array}{l}\text { 5.1. current and active participation in religious activities to enhance personal, } \\
\text { and spiritual aspects of life }\end{array}$ & 107 & 29 & 5 & 2.56 & WP & 2 \\
\hline $\begin{array}{l}\text { 5.2. regular attendance in church services, such as mass, Sunday school } \\
\text { classes or prayer meetings }\end{array}$ & 107 & 20 & 11 & 2.52 & WP & 4 \\
\hline $\begin{array}{l}\text { 5.3. traveling to sacred places (such as the Holy Land in Israel, grottos, Micah, } \\
\text { Vatican in Rome and local churches ) }\end{array}$ & 116 & 27 & 0 & 2.70 & WP & 1 \\
\hline $\begin{array}{l}\text { 5.4. meditating and reflecting on the scriptures, such as those in the Bible, } \\
\text { Kor'an, other religious books, lives of saints or prophets }\end{array}$ & 103 & 40 & 0 & 2.55 & WP & 3 \\
\hline \multicolumn{4}{|l|}{ Overall Mean } & 2.58 & $W P$ & \\
\hline
\end{tabular}

Legend: 2.51 - 3.00 "Well-Planned” (WA); 1:51 - 2.50" Planned" (A); and 1.00 -1.50” Not Planned" (NA).

MR: Mean Rating. R: Rank

\section{Conclusion and Recommendation}

\section{Conclusion}

Based on the findings the following conclusion was drawn: the pre-retirees" plan were all "well-planned" in selected well-being elements of pre-retirement, specifically in the areas of financial and health; but only "planned" in health, social and psychological.

\section{Recommendation}

Based on the conclusion the following recommendation was drawn: LGU must legalize the pre-retirement program in the LGU so the fiscal budgeting will be provided and be given to properly implementation of pre-retirement program in the LGU and lastly, LGU must enforce budgeting literacy though orientation, on the importance of budgeting to protect the retirees' ultimate income form their GSIS. Provide a complete pre-retirement health program. The LGU must encourage the retirees to engage social activities that will put to use their skills, knowledge, and experiences in the community. Psychological counseling will help retirees to lead happy, progressive, productive and meaningful life after pre-retirement. LGU should continue to the conduct of the religious rituals and show of respects for differences/diversities in the spiritual beliefs of the employees; and LGU should continue the practice of giving the testimonial to retirees. LGU should provide specific pre-retirement program specific for the pre-retiree

\section{REFERENCES}

[1] A Guide for Local Chief Executives (LCEs) on Public Personnel Administration of Civil Service Commission (accessed January 20, 2016)

[2] Baguio City holds pre-retirement forum Sunday, February 24, $2013 \quad$ (http://www.sunstar.com.ph/baguio/ local-news/city-holds-pre-retirement-forum-269856 retrieved October 4, 2014) (Angel Amadeo).
[3] Allessie, Rob JM (2011): Financial Literacy, Retirement Preparation and Pension Expectations in the Netherlands, De Nederlandsche Bank Working Paper No. 289

[4] Atchley, R \& Barush, AS (2004): Social Forces And Aging: An Introduction To Social Gerontology, Wadsworth, CA.

[5] Chow, R. (2009): Happiness and Life Satisfaction Lead to Better Health. accessed April 9, 2014

[6] Haveman, Robert and Holden, Karen and Wolfe, Barbara and Sherlund, Shane M., (2006): Do Newly Retired Workers in the United States Have Sufficient Resources to Maintain Well-Being? Economic Inquiry, Vol. 44, No. 2,pp. 249-264

[7] Haveman, Robert and Holden, Karen and Wolfe, Barbara and Romanov, Andrei, (2008): Assessing the Maintenance of Savings Sufficiency over the first Decade of Retirement CESifo Working Paper Series No. 1567.

[8] Hutcheson, Matthew D. (2007): Retirement Plan Disclosure: Ethical Principles and Legal Obligations: affiliation not provided to SSRN (Social Science Research Network).

[9] Joo S \& Pauwels V W (2002): Factors Affecting Retirement Confidence: A Gender Perspective; Journal of Financial Counseling and Planning 13(2) 2002 pp.1-10.

[10] Klingbeil, Erin (2011): Retirement Ten Commandments April 13, 2011,http://www.nasdaq.com/article/retirement-t en-commandments-cm70990\#ixzz3xw70Dcpc accessed January 23, 2016

[11] Lee, WKM, \& Law, KWK (2004): Retirement planning and retirement satisfaction: The need for a national retirement program and policy in Hong Kong', Journal of Applied Gerontology, Vol. 23, No 3, 212-233.

[12] Lynch, Merrill (2013): Retirement Study conducted in partnership with Age Wave Americans' Perspectives on New Retirement Realities and the Longevity Bonus

[13] PD 1146. Amending, Expanding, Increasing and Integrating the Social Security Benefits of Government Employees and Facilitating the Payments Thereof.

[14] Probasco, Jim, The Ten Commandments of Personal Finance November 30, 2015

http://www.investopedia.com/articles/personal-finance/102 915/ten-commandments-personal-finance.asp\#ixzz3xw8Kf fPi 
[15] Ranchor, Kempen, Suurmeijer (2004): The Relative Contribution of Domains of Quality of Life to Overall Quality of Life For Different Chronic Diseases. Northern Centre for Healthcare Research (NCH), Department of Health Sciences, University of Groningen, Netherlands. r.arnold@med.rug.nl

[16] Ra 7160. The Local Government of 1991

[17] RA 8291. Expanding and Increasing the Coverage and Benefits of the GSIS.

[18] RA 660. The Pre-Retirees by Choosing to Let Them Enjoy the Benefits.

[19] RA 1616. An Act Amending Section 12 of Commonwealth Act Numbered 106 .

[20] RA 7699. It is Considered As Take All Retirement Mode.

[21] RA 9994 or the "Expanded Senior Citizens Act of 2010
[22] Taylor, \& Doverspike, D. (2004) Retirement Planning. Beehr's and G. Adams (Eds) Retirement: Reasons, Processes and Results. New York: Springer Publishing.

[23] Rossi, Peter./ Lipsey, Mark W. Freeman, Howard E., (2004). Evaluation a Systematic approach $7^{\text {th }}$ Edition, Sage Publication.

[24] Schimmack, U 2006, 'Internal and External Determinants of Subjective Well-Being: Review And Policy Implications', In Y. K. Ng \& L. S. Ho (eds.), Happiness and public policy: Theory, case studies and implications. Palgrave Macmillan, New York.

[25] Veenhoven, R. (1991). Questions on Happiness: Classical Topics, Modern Answers, and Blind Spots. In Stack, F., Argyle, M. \& Schwartz, N. (Eds.), Subjective Well-Being: An Interdisciplinary Perspective (pp. 1-26). Elmsford, New York: Pergamon Press. 